\title{
Squamous Cell Carcinoma Arising in a Dermoid Cyst Ovary: A Rare Case Report
}

MALTI KUMARI MAURYA, MADHVI, MADHU KUMAR, SMRITI AGARWAL

\section{ABSTRACT}

Dermoid cysts account for approximately $25 \%$ of all ovarian tumors. Presence of pure squamous cell carcinoma is very rare findings $(1-2 \%)$, which is attributable to malignant transformations into a pre-existing dermoid cyst. As there are no specific signs and symptoms to suggest malignancy in dermoid cyst, therefore it is difficult to predict, and most cases are diagnosed post-operatively. We hereby report a case of dermoid cyst ovary with malignant
\end{abstract}

transformation into squamous cell carcinoma in 50 years post-menopausal women. Who presented with complaint of abdominal pain and increased frequency of micturation. Hysterectomy with Bilateral-salpingo-oophorectomy (BSO) with omentectomy was done. Right ovary showed huge cyst with hair shaft, sebaceous materials and a small solid area. Histopathological examination revealed squamous cell carcinoma was arising within the dermoid cyst.

\section{CASE REPORT}

A 50-year-old post menopausal woman presented with pain in abdomen with increased frequency of micturation since 1.5 years. She also developed off and on fever and vomiting for last 15 days. Finding of CT-scan was well defined peripherally enhancing cystic lesion in right ovary measuring $16.5 \times 13.5 \times 12.6 \mathrm{~cm}$ with heterogeneously enhancing soft tissue component with necrotic changes and fat fluid level extending from pelvis to umbilical region. Serum tumor markers: CA-125- $47.2 \mathrm{lU} / \mathrm{ml}$, CEA- $14.3 \mathrm{ng} / \mathrm{ml}$ and beta$\mathrm{HCG}$ was $7.85 \mathrm{mlU} / \mathrm{ml}$. The clinical differential diagnosis was malignant ovarian tumor or malignant teratoma. Peroperatively tumor was fixed to bowel wall. Total abdominal hysterectomy with bilateral salpingo-oophorectomy with omentectomy (TAH BSO) was done. Gross examination showed a cyst measuring $17.0 \times 14.0 \times 12.0 \mathrm{~cm}$. On cutting pultaceous material came out. Cut surface showed a bunch of hair and a gray white solid area measuring $6.0 \times 5.5 \mathrm{~cm}$ with foci of necrosis [Table/Fig-1]. Microscopic examination showed cyst lined by stratified squamous epithelium with adenexal structures, keratin flakes and hair follicles [Table/ Fig-2 A and B]. Sections from solid area revealed malignant tumor (squamous cell carcinoma) arising from lining of cyst wall and proliferating in form of solid sheets and nests with comedonecrosis pattern. Tumor was moderately differentiated with occasional keratin pearls [Table/Fig-3 $A$ and B]. P63 immunostaining showed diffuse nuclear

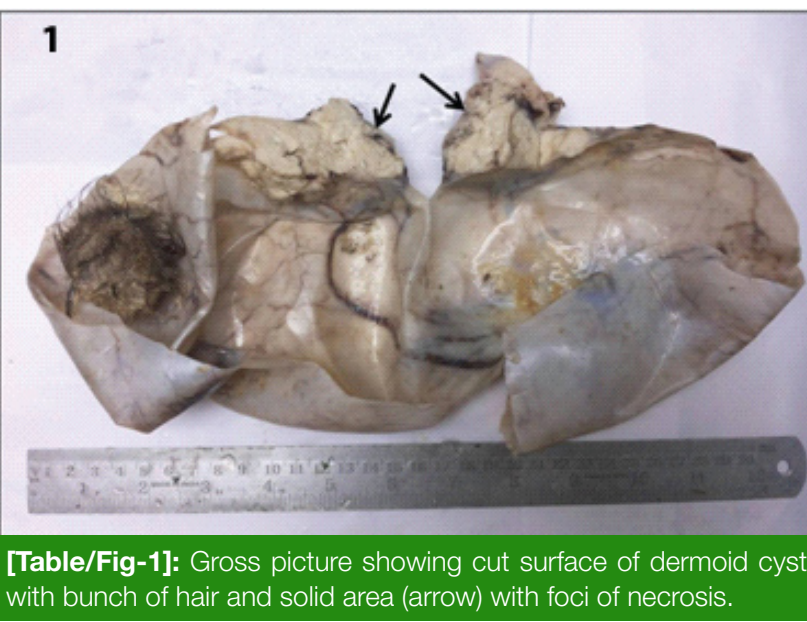

positivity in tumor cells [Table/Fig-3C and D]. Omentum showed positive peritoneal deposits. Post operative period was uneventful and patient was referred to medical oncology unit for further management, where adjuvant chemotherapy was started. Prognosis was very poor. After two weeks she developed ascitis and breathlessness and did not respond to medical treatment. Unfortunately patient lost the follow up.

\section{DISCUSSION}

Mature cystic teratoma also known as the dermoid cyst, which accounts for $25 \%$ of all ovarian tumors. It is usually found in young women during reproductive years [1]. These 

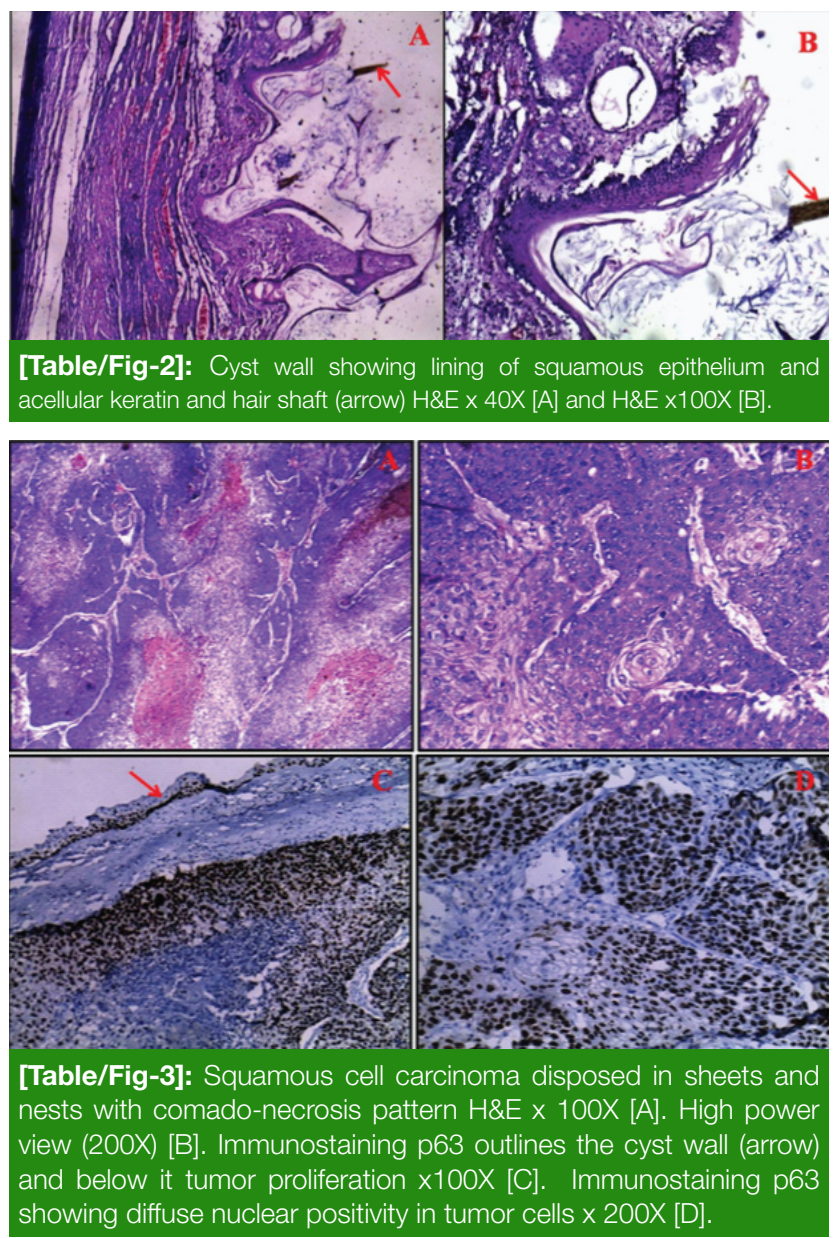

tumors often grow slowly and go unnoticed till they become very large. About $1-2 \%$ of dermoid cyst undergo malignant transformation, are most commonly seen in postmenopausal women and associated with poor prognosis [1,2]. Mature cystic teratoma are unilocular/multilocular cysts contain hairs, sebaceous material and other tissues derived from embryonic germ layers which have potential to develop malignancy of divergent histomorphological types. The majority of such malignancies arising within ovarian dermoid are: squamous cell carcinoma (80\%) followed by adenocarcinoma, carcinoid tumors and melanoma $[3,4]$. The denovo development of SCC in otherwise healthy ovary is extremely rare [5]. Preoperative diagnosis is difficult [6]. These tumors commonly spread through direct and local invasion rather than lymphatic or hematogenous route [7]. Clinical behavior of these tumors is unpredictable and the role of chemotherapy and radiotherapy remains unclear.

Most patients are asymptomatic or have symptoms of abdominal distension. As the tumor increases in size patient can present with compressing symptoms like gastrointestinal symptoms diarrhoea/constipation, rectal bleeding or urinary frequency [8]. Our patient had complained of abdominal pain and urinary frequency for 1.5 years.
Grossly in dermoid cyst there may be solid area having different types of tissue like cartilage, bone, soft tissue and hairs. If there is solid friable area with any sign of necrosis hemorrhage or irregular plaque and thickened area in the cyst wall, then it should be sampled carefully to rule out immature component or malignant transformation in the cyst $[1,4]$. Histopathological examination plays an important role in confirmation of diagnosis and treatment planning. In our case there was typical histology of dermoid cyst but the solid area showed various stages of development from dysplasia to frank invasion (malignancy). Tumor cells were proliferated in the form of solid sheets and nests in desmoplastic stroma with occasional keratin peals and large area of necrosis. P63 was diffusely positive in tumor cells [Table/Fig-3C and D]. In our case differential diagnosis was malignant teratoma but we did not find other tumor component like sarcoma, immature neural component, melanoma or poorly differentiated tumor cells. Hence, the case was considered as pure squamous cell carcinoma arising in a dermoid cyst ovary.

The risk factors for malignant change in dermoid cyst are advance age more than 40 years, tumor size $>10 \mathrm{~cm}$, rapid growth and increased tumor markers [9,10]. James R Powell et al., in their study observed that mean age of malignant transformation in dermoid cyst was 55 years [11]. Kikkawa et al., in their case series found that tumor diameter larger than $9.9 \mathrm{~cm}$ was $86 \%$ sensitive for malignant change [10]. In our case the age of patient was 50 years, tumor diameter was 17 $\mathrm{cm}$ and tumor marker CEA (14.3 ng/ml) and CA-25(47.2 IU/ $\mathrm{ml}$ ) were elevated. Mori et al., reported that age $>40$ years, serum SCC antigen $>2.5 \mathrm{ng} / \mathrm{ml}$ were $71 \%$ sensitive and $96 \%$ specific for malignant transformation which has also been useful in monitoring for recurrent disease [12]. Due to rarity of lesion as well as incidental nature of diagnosis, the definitive therapy for squamous cell carcinoma arising in a ovarian dermoid has not yet been established [13]. In stage-I disease with postmenopausal women total abdominal hysterectomy with bilateral salpingo-oophorectomy and omentectomy (TAH-BSO) is procedure of choice. While in younger patients who wish to preserve fertility, unilateral oophorctomy may be done. Patient with stage II or III disease required optimal debulking followed by combination of chemotherapy and radiotherapy $[4,8,13,14]$. JL Hurwitz et al., suggested that repeated surgical resection of disease at the time of relapse could give a very durable response in selected women. In their case series they observed no definite benefit from chemotherapy to any of their patients [14]. James R Powell in their case series used platinum based chemotherapy and out of six only two patient have partial response [11]. The prognosis for these tumors has often been reported to be poor with a five year survival rate of only $15-30 \%[2,9]$. The potential predictors reported include FIGO stage, residual 
tumor, rupture or spillage, tumor grade, vascular involvement and the mode of tumor infiltration [10]. Meta-analysis of published data suggests that chemotherapy regimen containing alkylating agents might improve overall survival [4]. Some studies have shown that remarkable responses have achieved with paclitaxel based regimen combined with pelvic radiation [13].

\section{CONCLUSION}

Squamous cell carcinoma arising in dermoid cyst ovary is rare occurrence with poor outcome. Risk factors are age over 45 years, tumor diameter greater than $10 \mathrm{~cm}$ and increase serum tumor markers CEA and SCC antigen. Tumors confined to the ovary, usually have a better prognosis. Awareness to this rare entity would help in early diagnosis and better management of older patients with dermoid cysts.

\section{REFERENCES}

[1] Young RH, Clement PB, Scully RE. Sex Cord - Stromal, Steroid Cell, and Germ Cell Tumors of the Ovary. Chapter 55. In Sternberg's Diagnostic Surgical Pathology. $4^{\text {th }}$ edition Vol 3; 2579-615.

[2] Powell JL, Stinson JA, Connor JP, Shiro BS, Mattison M. Squamous cell carcinoma arising in dermoid cysts of the ovary. Gynecol Oncol. 2003;89:526-28.

[3] Hackethal A, Brueggmann D, Bohlmann MK et al, Squamous cell carcinoma in mature cystic teratoma of the ovary: Systemic review and analysis of public data. Lancet Oncol. 2008;9;1173-80.

[4] Rosai J. Female Reproductive System, Chapter 19. In: Rosai J, editor. Ackerman's Surgical Pathology. $9^{\text {th }}$ ed., Vol 2 St Louis: Mosby; 2004,1649-736.
[5] Chien SC, Sheu BC, Chang WC, Wu MZ, Huang SC. Pure primary squamous cell carcinoma of the ovary: a case report and review of the literature. Acta Obstet Gynecol Scand. 2005;84: 706-08.

[6] Lucksom PG, Sebastian N, Pradhan D, Ritu R. Malignant transformation of ovarian dermoid: a rare case. Int $\mathrm{J}$ Reprod Contracept Obstet Gynecol. 2013;2:698-700.

[7] Czernobilsky B, Mercer BL, Roth LM. The ovary \& Fallopian Tube Chapter 52. In: Principles and Practice of Surgical Pathology \& Cytopathology. Steven G. Silverberg, $3^{\text {rd }}$ ed. Vol. 3; 2525-74.

[8] Tekwani DT, Joshi SR, Kudrimoti MM, Korde VR. Malignant transformation in an ovarian mature cystic teratoma: A case report. Indian journal of basic and applied medical research. 2012;5(2);432-35.

[9] Lucksom PG, Sebastian N, Pradhan D, Ritu R. Malignant transformation of ovarian dermoid: a rare case. Int $\mathrm{J}$ reprod contracept obstet gynecol. 2013:2(4);698-700.

[10] Kikkawa F, Nawa A, Tamakoshi K, et al. Diagnosis of squamous cell carcinoma arising from mature cystic teratoma of the ovary. Cancer. 1998 ; 82(11):2249-55.

[11] Powell JR, Haldar K. Squamous cell carcinoma arising in a mature cystic teratoma of the ovary: a case series and review of the literature. European Oncology \& Haematology . 2013;9(1):1720.

[12] Mori $Y$, Nishii $H$, Takabe $K$, et al. Preoperative diagnosis of malignant transformation arising from mature cystic teratoma of the ovary. Gynecol Oncol. 2003; 90(2):338-41.

[13] Kumar N, Chhabra S, Singh A. Coexistence of Squamous cell carcinoma with dermoid cyst of ovary: A case report. Int $\mathrm{J}$ of Biomed and Adv Research. 2013;04(03):203-06.

[14] Hurwitz JL, Fenton A, McCluggage WG, McKenna S. Squamous cell carcinoma arising in a dermoid cyst of the ovary: a case series. BJOG. 2007;114:1283-87.

\section{AUTHOR(S):}

1. Dr. Malti Kumari Maurya

2. Dr. Madhvi

3. Dr. Madhu Kumar

4. Dr. Smriti Agarwal

\section{PARTICULARS OF CONTRIBUTORS:}

1. Assistant Professor, Department of Pathology, King George Medical University, Lucknow, India.

2. Post Graduate Student, Department of Pathology, King George Medical University, Lucknow, India.

3. Assistant Professor, Department of Pathology, King George Medical University, Lucknow, India.
4. Associate Professor, Department of Obstetrics and Gynecology, King George Medical University, Lucknow, India.

\section{NAME, ADDRESS, E-MAIL ID OF THE} CORRESPONDING AUTHOR:

Dr. Malti Kumari Maurya,

Assistant Professor, Department of Pathology, King George Medical University, Lucknow-226003, India.

E-mail: mauryamalti@yahoo.co.in

FINANCIAL OR OTHER COMPETING INTERESTS: None.

Date of Publishing: Apr 01, 2016 